\title{
Comparisons of 4-Point GRBAS, 7-Point-GRBAS, and CAPE-V for Auditory Perceptual Evaluation of Dysphonia
}

\author{
Seong Hee Choi ${ }^{1,2}$, Miok Yu' ${ }^{2}$, Chul-Hee Choi ${ }^{1,2}$ \\ 'Department of Audiology \& Speech-Language Pathology, College of Bio and Medical Sciences, Research Institute of Biomimetic Sensory Control, and \\ Catholic Hearing Voice Speech Center, Daegu Catholic University, Gyeongsan, Korea \\ ${ }^{2}$ Graduate Program in Audiology \& Speech-Language Pathology, Daegu Catholic University, Gyeongsan, Korea
}

Received: November 23, 2020

Revised: January 6, 2021

Accepted: January 25, 2021

\section{Correspondence:}

Seong Hee Choi, PhD

Department of Audiology \& SpeechLanguage Pathology,

College of Bio and Medical Sciences,

Research Institute of Biomimetic

Sensory Control, and

Catholic Hearing Voice Speech Center,

Daegu Catholic University,

13-13 Hayang-ro, Hayang-eup,

Gyeongsan 38430 , Korea

Tel: $+82-53-850-2542$

Fax: +82-53-359-6780

E-mail: shgrace@cu.ac.kr
Purpose: The GRBAS (grade, roughness, breathiness, asthenia, strain) scale, a 4-point scale, has been most widely used for judging auditory-perceptual severity for dysphonia. However, in current clinical practice, sometimes a more fragmented 0.5 scheme is being used if the original GRBAS scale is ambiguous to assess. Thus, the aim of the present study was to compare the dysphonia severity using the three auditory-perceptual evaluation tools, 4-point, 7-point GRBAS scale, and CAPE$\checkmark$ and provide the information regarding differentiation of perceptual severity and acoustic correlations. Methods: Voice samples for sustained vowel and connected speech were obtained from 101 dysphonic patients. Auditory-perceptual assessments of dysphonia severity were performed by two certified experienced speech-language pathologists specializing in voice disorders using the grade of a 4-point and a 7-point GRBAS, OS of CAPE-V and also were compared with cepstral measures [cepstrum peak prominence (CPP), low/high spectral ratio]. Results: OS and G of inter-rater reliability of dysphonia using CAPE-V and 4-point GRBAS scales were good (ICC > 0.800) while G of 7-point GRBAS was less strong (ICC > 0.681) than OS of CAPE-V and G of 4-point GRBAS scale. The highest correlation with CPP was the OS of CAPE-V in both vowel and connected speech, while $\mathrm{L} / \mathrm{H}$ ratio showed low correlation with dysphonia severity. The OS of CAPE- $V$ in vowel and connected speech differed significantly in G of both GRBAS scales. On the 4-point GRBAS scale, CPP showed only the difference between G1-G2, G2-G3 groups in /a/ vowel, whereas in the connected speech, the difference between G0-G1, G1-G2, and G2-G3 groups was relatively differentiated. Meanwhile, on a 7-point GRBAS scale, CPP showed only differences between G1.5-G2 groups in sustained vowel, while CPP showed no differences between G0-G0.5, G0.5-G1, G1-G1.5, G2-G2.5, and G2.5-G3 groups respectively in connected speech. Conclusion: 7-point GRBAS scale showed a higher correlation with CPP measures than the original GRBAS, but reduced the discrimination of dysphonia severity compared to the 4-point GRBAS scale. Consequently, modified 7-point GRBAS scale could be useful as a clinically-perceptual evaluation tool, along with the original GRBAS scale and CAPE-V.

Key Words: 4-Point GRBAS, 7-Point GRBAS, Consensus Auditory-Perceptual Evaluation of Voice, Dysphonia, Cepstral analysis.

\section{INTRODUCTION}

청지각적 평가는 전통적으로 임상에서 음성장애 환자의 음 성 평가 방법 중 정석(gold standard)으로 불리우는 가장 필수 적인 검사로, 훈련된 임상가의 귀에 의해 평가되는 임상가 기반 의 주관적인 평가이다. 청지각적 평가는 객관적 검사에서 평가 할 수 없는 복잡한 음질에 대한 특성을 평가할 수 있으며, 장비

(cc) This is an Open Access article distributed under the terms of the Creative Commons Attribution Non-Commercial License (https://creativecommons.org/licenses/by-nc/4.0) which permits unrestricted non-commercial use, distribution, and reproduction in any medium, provided the original work is properly cited.
를 사용하지 않고 음성장애 유무와 중증도를 평가하고(Bele, 2005; Bhuta et al., 2004), 치료의 효과를 예측하는 데도 중요 하게 사용된다(Ma \& Yiu, 2006).

국내 음성 평가에 관한 임상가 참여 전국 조사 결과, 현재 음 성 평가 업무를 담당하고 있는 국내 음성언어재활사 중 응답자 $100 \%$ 가 정기적으로 음성 평가 시 청지각적 평가를 시행하고 있으며, 이 중 grade, roughness, breathiness, asthenia, strain (GRBAS) (Hirano, 1981)척도나 Consensus Auditory-Perceptual Evaluation of Voice (CAPE-V) (Kempster et al., 2009)를 사용하는 것으로 나타났다(Choi, 2013). 하지만 검사자의 경험 
과 훈련 정도에 따라 검사자 간 및 검사자 내 신뢰도에 문제가 제기되어 왔다(Eadie \& Baylor, 2006).

한편, 음성을 청지각적으로 평정할 때 척도(scale)를 사용하 게 되는데, 서열척도(ordinal scale, ORD)나 등간격척도(equalappearing interval scale, EAI), 혹은 시각적 아날로그 척도 (visual analog scale, VAS)와 같은 연속 척도를 사용한다(Choi \& Choi, 2009; Kreiman et al., 1993).

현재 가장 널리 사용되고 있는 대표적인 청지각적 평가 도구 중 일본음성언어의학회에서 완성된 GRBAS척도는 G (grade, 종합애성도), R (roughness, 조조성), B (breathiness, 기식성), A (asthenia, 무력성), S (strain, 긴장성)로 5개의 항목으로 이 루어져 있다. 평가 척도는 서열 척도(ordinal scale)와 같은 리커 트 척도를 사용하며 총 4점 척도로 0 점은 정상, 3점은 가장 안 좋은 음질의 상태를 의미한다. 즉, 0 은 정상, 1 은 경도(mild), 2 는 중도(moderate), 3 은 심도(severe)를 나타낸다. 청지각적 파 라미터 중 종합애성도 $(\mathrm{G})$ 는 음질의 전체적인 인상을 나타내며, 조조성(R)은 성대 진동이 불규칙하게 나타나는 소리로 거친 소 리이고, 긴장성(S)은 성대가 비정상적으로 과긴장하여 성대가 과도하게 단단하여 쥐어짜는 듯한 소리를 나타낸다. 기식성(B) 은 성문폐쇄부전으로 인해 공기가 새는 소리로서 간혹 무력성 과 혼돈이 올 수 있어서 구분하여 평가하여야 한다. 이러한 이 유로 성대긴장부전으로 인한 연약하고 갸날픈 소리를 나타내는 무력성(A)은 CAPE-V에서는 무력성을 제외하고 음질을 평가 한다. 또한, GRBAS척도는 다른 청지각적 평정 척도에 비해 검 사자의 숙련도에 큰 영향을 받지 않으며, 검사자 간 신뢰도가 높아 평가가 용이하다고 보고되었다(Bhuta et al., 2004). 그 중 에서도 음성의 전체적인 애성도를 평가하는 $\mathrm{G}$ 는 객관적 음성 평가와의 상관관계가 높은 것으로 알려져 있다(Anders et al., 1988). 이에 반해 GRBAS척도는 CAPE-V와 비교했을 때 평가 항목 수가 적고, 척도도 4단계로 단조로운 구성을 가지고 있어 섬세하고 세부적인 음질 평가가 어려우며, 음도, 강도를 평가하 지 못하고 음질만 평가하는 단점이 있다. 하지만, 다른 청지각 적 평정 도구보다 더 빠르고 쉽게 검사가 가능하고 재현성이 뛰 어나 지금까지의 청지각적 평정 중에 가장 우수하다고 평가되 었다(Karnell et al., 2007; Wuyts et al., 1999).

2002년에 미국언어병리학회(American Speech-LanguageHearing Association, ASHA)에서 발표된 CAPE-V는 이전의 단점들을 보완한 청지각적 평정 도구이다. 최근 미국을 포함한 여러 국가에서 GRBAS척도를 대신하여 많이 사용하고 있으며, $\mathrm{CAPE}-\mathrm{V}$ 는 모음, 문장 및 자발화 샘플을 듣고 전반적인 중증 도(overall severity, $\mathrm{OS})$, 조조성 $(\mathrm{R})$, 기식성(B), 긴장성(S), 음소 (pitch, P), 강도(loudness, L) 총 6개의 항목으로 이루어져 검사 자가 평정하게 되어 있다. 또한, 추가로 성대프라이, 떨림, 공명,
이중 음성, 젖은 목소리, 가성 발성, 실성증, 불안정한 음도 등 을 평가한 후 $100 \mathrm{~mm}$ 선상에 표시하는 시각적 아날로그 척도 (VAS)를 사용한다(Kempster et al., 2009). 즉, $0 \mathrm{~mm}$ (정상) 부터 $100 \mathrm{~mm}$ (가장 안 좋은 음질의 상태)까지 나타낼 수 있는 연속 척도이다. GRBAS척도는 음질만 평가가 가능한 반면, $\mathrm{CAPE}-\mathrm{V}$ 는 음도, 강도 및 음질을 전반적으로 모두 평가할 수 있 다. 하지만, CAPE-V는 GRBAS척도에 비해 검사자 간 신뢰도 가 낮은 반면, $\mathrm{CAPE}-\mathrm{V}$ 는 GRBAS척도에 비해 작은 차이를 감 지하는 민감도가 더 높은 것으로 보고되었다(Karnell et al., 2007; Wuyts et al., 1999).

위의 청지각적 평정 척도의 단점을 보완하여 현재 임상에서 는 GRBAS척도의 4점 체계로 평정하기 어려운 경우, 좀 더 세 분화된 척도로서 원래의 $0,1,2,3$ 의 4점 척도를 세분화하여 0 (normal), 0.5 (very mild), 1 (mild), 1.5 (mild-to-moderate), 2 (moderate), 2.5 (moderate-to-severe), 3 (severe)으로 7점 GRBAS척도를 사용하기도 한다. 하지만 임상이나 연구에서 많 이 사용하고 있음에도 불구하고 아직까지 세분화된 7점 GRBAS 척도와 기존의 GRBAS척도 및 $\mathrm{CAPE}-\mathrm{V}$ 의 청지각적 평정에 대한 비교 연구가 이루어진 바가 없다. 따라서, 본 연구는 음성장애의 중증도를 평가하기 위하여 기존의 GRBAS척도와 7점 GRBAS 척도의 $\mathrm{G}$ 점수와 $\mathrm{CAPE}-\mathrm{V}$ 의 전반적인 중증도를 비교하여 7점 GRBAS척도의 임상적 유용성을 살펴보고자 한다.

한편, 최근 ASHA에서는 장애 음성을 평가하는 데 있어서 캡 스트럼 분석 측정치를 포함하도록 권고하고 있다(Patel et al., 2018). 캡스트럼 분석은 음질을 객관적으로 평가하는 음향학적 분석 방법 중 하나로서 청지각적 평정을 보완하기 위하여 사용 된다. 특히, 청지각적 평정을 위한 음성 샘플로는 모음뿐 아니 라 일상생활의 음성을 가장 잘 반영하는 연속 구어의 말 과제 를 함께 사용하는데 캡스트럼 분석은 모음뿐 아니라 연결 발화 의 분석도 가능하며, 음성 문제가 심각한 경우에도 음질을 객 관적으로 분석할 수 있다(Choi \& Choi, 2014). 뿐만 아니라 캡 스트럼 측정치는 모음 연장 발성 및 연결 발화 음성 표본에서 장애 음성의 중증도를 강력하게 예측할 뿐 아니라, 청지각적 평 가와 높은 상관을 보인다고 하였다(Awan et al., 2010; Choi \& Choi, 2014, 2016; Lowell et al., 2012; Yu et al., 2017). 따라서, 첫째, 본 연구는 모음과 연결 발화에서 기존의 4점 GRBAS척도 와 7점 $\mathrm{GRBAS}$ 척도 및 $\mathrm{CAPE}-\mathrm{V}$ 를 사용하여 음성장애 중증도 에 대한 평가자 내 및 평가자 간 신뢰도를 비교해 보고자 한다. 둘째, 4점 및 7점 GRBAS척도와 CAPE-V에 따른 청지각적 중 증도를 비교해 보고자 한다. 셋째, 청지각적 음질의 객관적 지 표로 널리 알려진 켑스트럼 측정치와 청지각적 평가들 간 상관 성을 살펴봄으로써 어떤 청지각적 평가 척도가 중증도를 잘 변 별할 수 있는 지 살펴보고자 한다. 
Table 1. Distribution of disease of the pathologic voice samples according to age (17 to 80 years) and gender $(n=101)$

\begin{tabular}{lcc}
\hline Disease & Male & Female \\
\hline Nodules & 7 & 28 \\
Polyp & 4 & 3 \\
MTD & 0 & 26 \\
ADSD & 0 & 6 \\
Cyst & 2 & 4 \\
Parkinson & 1 & 0 \\
Sulcus & 9 & 7 \\
Scar & 2 & 2 \\
\hline
\end{tabular}

MTD: muscle tension dysphonia, ADSD: adductor spasmodic dysphonia

\section{MATERIALS AND METHODS}

\section{연구 대상}

본 연구는 목소리 문제를 주소로 내원한 환자 중 음성장애 로 진단받은 환자 101 명을 대상으로 하였다. 대상 환자는 후두 내시경 검사를 통해 이비인후과 전문의의 진단을 받고 음성치 료사의 음성 검사를 받은 환자들로 대상 환자의 연령은 만 17 80세로 평균 연령은 47.4세였으며, 남성 25명, 여성이 76명 이었다. 대상자의 정보는 Table 1과 같다.

\section{연구 절차}

음성자료 수집을 위해 소음이 통제된 이비인후과 음성검사 실에서 $90^{\circ}$ 로 고정된 Shure SM48-LC 다이내믹 마이크(Shure Inc., Chicago, IL, USA)를 이용하여 Computerized Speech Lab (CSL; KayPENTAX Inc., Lincoln Park, NJ, USA)의 Real Time Pitch 프로그램(Model 5121, KayPENTAX Inc.)을 사용하여 녹음하였다. 이때, 음성표본추출률(sampling rate)은 $44,100 \mathrm{~Hz}, 16$ bit 양자화로 하였다. 모음 연장 발성 과제는 편 안하고 자연스러운 음도와 강도로 모음 / / 를 3초간 발성하도 록 하였고 연속 구어 과제는 "안녕하세요? 제 이름은 $\bigcirc \bigcirc$ 입니 다."를 평상시의 습관적인 음도와 강도로 말하도록 하였다.

\section{청지각적 평정}

청지각적 평정은 소음이 통제된 $30 \mathrm{~dB}$ 미만의 조용한 방에서 음성장애 환자의 평가와 치료 영역의 15 년 이상(평균 18.3년)인 2 명의 1 급 언어재활사(1명의 음성클리닉에 근무하는 언어재활 사, 1 명의 교수)에 의해 실시되었다. 모음 연장 발성과 연결 발화 의 두 가지 음성 표본은 실험대상자의 정보 없이 WAV 형식으 로 모음 파일과 연결 발화 파일에 각각 저장되었다. 청지각적 평가는 음성장애 중증도를 평가하기 위하여 음질의 중증도를 평가하는 데 널리 사용되는 GRBAS척도와 세분화된 GRBAS
척도 중 $\mathrm{G}$ 를, $\mathrm{CAPE}-\mathrm{V}$ 에서는 전반적 중증도 $(\mathrm{OS})$ 를 중심으로 측정하였다. 모든 검사자는 전체 101 명의 음성 샘플 총 202개 (모음 101개, 연결 발화 202개)를 듣고 음성 샘플에 대한 사전 정보 없이 청지각적 평정을 실시하였으며, 모든 음성 평가는 필 요한 경우 반복적으로 듣도록 허용하였다. 무작위로 배치된 모 음 파일을 듣고 4점 GRBAS척도, 7점 GRBAS척도, $\mathrm{CAPE}-\mathrm{V}$ 를 사용하여 동시에 $\mathrm{G}$ 점수와 $\mathrm{OS}$ 를 평정하였다. 그 후 연결 발 화를 듣고 동일한 방법으로 청지각적 평가를 실시하였다. 반복 된 청지각적 검사의 피로나 집중력의 감소를 조절하기 위하여 검사자는 30 개의 샘플 평정 후 10 분간 휴식 시간을 가지도록 하 였다. 첫 번째 청지각적 평정에서 모든 음성 샘플에 대한 청지각 적 평정을 실시하였으며, 검사자 간 일치도를 측정하기 위하여 청지각적 평정 점수들을 비교하였다. 검사자 내 신뢰도를 측정 하기 위해 일주일 후 전체 샘플의 $30 \%$ 에 해당하는 34 명의 음성 샘플 총 68개(모음 34개, 연결 발화 34개)를 무작위로 추출하여 재평가를 실시하였다. 평정 후 캡스트럼의 음향학적 상관을 비 교하기 위해 판정이 일치하지 않은 음성 표본은 4점 GRBAS척 도와 7점 GRBAS척도의 경우, 두 명의 언어재활사가 함께 음 성을 듣고 재평정 후 최종 동의한 것을 측정치로 사용하였으며, $\mathrm{CAPE}-\mathrm{V}$ 는 각 평정자 측정치의 평균값을 사용하였다.

\section{음향학적 평가}

녹음된 음성 자료는 Analysis of Dysphonia in Speech and Voice (ADSV, Model 5109; KayPENTAX Inc.)의 프로그램을 사용하여 캡스트럼 피크 현저성(cepstrum peak prominence, $\mathrm{CPP}$ ), 저주파수 대 고주파수 스펙트럼 에너지 비율(low/high spectral ratio, $\mathrm{L} / \mathrm{H}$ ratio)을 측정하였다. 모음 연장 발성의 분석 은 / / / 모음을 3초간 발성한 음성 표본의 처음과 끝부분의 50 $\mathrm{ms}$ 를 제외한 구간 중 2 초를 분석하였다. 연결 발화는 대상자의 이름을 넣어 "안녕하세요? 저는 대구광역시에 사는 $\bigcirc \bigcirc \bigcirc$ 입니 다.”를 사용하였으며, 이름과 쉼 구간은 분석에서 제외하였다.

\section{통계 분석}

SPSS (Statistics Package for Social Science version 19.0, IBM Corp., Armonk, NY, USA)를 이용하여 통계 분석을 실 시하였다. / / / 연장 모음 및 연결 발화에 대한 4점 GRBAS척도 의 $\mathrm{G}$ 점수와 7점 $\mathrm{GRBAS}$ 척도의 $\mathrm{G}$ 점수 및 $\mathrm{CAPE}-\mathrm{V}$ 의 전반적 중증도(OS)의 검사자 내 및 검사자 간 신뢰도를 살펴보기 위하 여 급내상관계수(intraclass correlation coefficients, ICCs)를 측정하였다.

모음 연장 발성과 연결 발화의 4점 GRBAS척도의 $\mathrm{G}$ 점수와 7점 $\mathrm{GRBAS}$ 척도의 $\mathrm{G}$ 점수의 중증도 집단 간 $\mathrm{CAPE}-\mathrm{V}$ 의 $\mathrm{OS}$ 평 균 점수의 차이를 살펴보기 위하여 일원분산분석(one-way 
analysis of variance)을 각각 실시하였다. 집단 간 차이를 살펴 보기 위하여 사후 검정을 실시하였으며, 유의 수준은 Bonferroni 방법으로 교정하여 4점 GRBAS척도 집단은 0.0125 , 7점 GRBAS척도 집단은 0.007로 하였다. 또한, 모음 연장 발성과 연 결 발화의 4점 GRBAS척도와 7점 GRBAS척도의 중증도 집단 (G) 및 $\mathrm{CAPE}-\mathrm{V}$ 의 중증도 집단(OS) 간 캡스트럼 측정치의 차 이를 살펴보기 위하여 일원분산분석을 실시하였다. 집단 간 차 이를 살펴보기 위하여 사후 검정을 실시하였으며, 위와 동일한 방법으로 유의 수준을 검증하였다. 캡스트럼 측정치와 청지각 적 분석치 간 상관성을 살펴보기 위하여 스피어만 상관분석을 실시하였으며, 통계적 유의성 검증은 0.05 로 하였다.

\section{RESULTS}

\section{검사자 내 및 검사자 간 신뢰도}

두 명의 검사자 내에서 청지각적 평정의 급내상관계수는 Table 2와 같다. 4점 $\mathrm{GRBAS}$ 척도의 $\mathrm{G}$ 는 / / / 모음 $(\mathrm{ICC}=0.887$ 0.941) 과 연결 발화 $(\mathrm{ICC}=0.928 \sim 0.947)$ 에서 강한 상관관계를 보였 으며, 7점 $\mathrm{GRBAS}$ 척도의 $\mathrm{G}$ 는 / / / 모음과 연결 발화는 각각 0.828 0.883, 0.896 0.901로 비교적 높은 상관관계를 나타내 었다. 이와 마찬가지로, $\mathrm{CAPE}-\mathrm{V}$ 의 OS 점수는 / / / 모음 $(\mathrm{ICC}=$

Table 2. Intrarater reliability coefficients for the $G$ of 4-point and 7-point GRBAS scale and OS of CAPE-V

\begin{tabular}{llll}
\hline & \multirow{2}{c}{ ICC } & \multicolumn{2}{c}{$95 \%$ CI } \\
\cline { 3 - 4 } & & Lower limit & Upper limit \\
\hline OS of CAPE-V-Vowel & 0.899 & 0.686 & 0.976 \\
J1 & 0.948 & 0.886 & 0.989 \\
J2 & & & \\
OS of CAPE-V-Speech & 0.909 & 0.826 & 0.952 \\
J1 & 0.897 & 0.786 & 0.922 \\
J2 & & & \\
G of 7-point GRBAS-Vowel & 0.828 & 0.622 & 0.961 \\
J1 & 0.883 & 0.675 & 0.902 \\
J2 & & & \\
G of 7-point GRBAS-Speech & & 0.721 & 0.967 \\
J1 & 0.901 & 0.729 & 0.963 \\
J2 & 0.896 & & \\
G of 4-point GRBAS-Vowel & & & 0.948 \\
J1 & 0.887 & 0.752 & 0.979 \\
J2 & 0.941 & 0.832 & 0.977 \\
G of 4-point GRBAS-Speech & & & 0.981 \\
J1 & 0.928 & 0.776 & \\
J2 & 0.947 & 0.847 & \\
\hline
\end{tabular}

GRBAS: grade, roughness, breathiness, asthenia, strain, OS: overall severity, CAPE-V: Consensus Auditory-Perceptual Evaluation of Voice, ICC: intraclass correlation coefficients, CI: confidence interval
0.899 0.948)과 연결 발화(ICC $=0.897$ 0.909)에서 모두 비교 적 높은 상관성을 나타내었다 $(p<0.001)$.

한편, 모음과 연결 발화에 대한 평가자 간 일치도는 CAPE$\mathrm{V}$ 는 OS의 급내상관계수는 0.897 0.921로 강한 상관성을 보였 다. 반면, 7점 GRBAS척도의 $\mathrm{G}$ 는 0.681 0.731로 CAPE-V의 $\mathrm{OS}$ 보다는 낮은 중간 정도의 일치도를 보였으며, 4점 GRBAS척 도의 $\mathrm{G}$ 는 중간 $(\mathrm{ICC}=0.800$, 모음)에서 비교적 높은 일치도 (ICC $=0.878$, 연결 발화)를 보였다(Table 3).

\section{4점 GRBAS척도 vs. 7점 GRBAS척도에 따른 청지각적 평정}

4점 GRBAS척도와 7점 GRBAS척도를 사용하여 모음과 연 결 발화에 대한 청지각적 평정 결과는 Table 4와 같다.

Table 3. Interater reliability for the G of 4-point and 7-point GRBAS scale and OS of CAPE-V

\begin{tabular}{lccc}
\hline \multirow{2}{*}{ Auditory evaluation } & \multirow{2}{*}{ ICC } & \multicolumn{2}{c}{$95 \%$ CI } \\
\cline { 3 - 4 } & & Lower limit & Upper limit \\
\hline OS of CAPE-V & & & \\
$\quad$ Vowel & 0.897 & 0.786 & 0.952 \\
$\quad$ Speech & 0.921 & 0.849 & 0.959 \\
G of 7-Point GRBAS & & & \\
$\quad$ Vowel & 0.731 & 0.492 & 0.868 \\
$\quad$ Speech & 0.681 & 0.412 & 0.841 \\
G of 4-Point GRBAS & & & \\
$\quad$ Vowel & 0.800 & 0.608 & 0.904 \\
$\quad$ Speech & 0.878 & 0.664 & 0.959 \\
\hline
\end{tabular}

GRBAS: grade, roughness, breathiness, asthenia, strain, OS: overall severity, CAPE-V: Consensus Auditory-Perceptual Evaluation of

Voice, ICC: intraclass correlation coefficients, CI: confidence interval

Table 4. Perceptual ratings using GRBAS scale (4-point GRBAS vs. 7-point GRBAS) in sustained /a/ vowel and connected speech

\begin{tabular}{lrc}
\hline \multicolumn{1}{c}{ Scale } & Vowel & Speech \\
\hline 4-point GRBAS & & \\
G0 & 27 & 26 \\
G1 & 37 & 40 \\
G2 & 25 & 24 \\
G3 & 12 & 11 \\
Total & 101 & 101 \\
7-point GRBAS & & \\
G0 & 13 & 29 \\
G0.5 & 26 & 18 \\
G1 & 17 & 16 \\
G1.5 & 17 & 12 \\
G2 & 13 & 12 \\
G2.5 & 8 & 10 \\
G3 & 7 & 4 \\
Total & 101 & 101 \\
\hline GRBS: grade, & & \\
\hline
\end{tabular}

GRBAS: grade, roughness, breathiness, asthenia, strain 
Table 5. Mean overall severity of Consensus Auditory-Perceptual Evaluation of Voice according to grade scores in 4-point GRBAS (grade, roughness, breathiness, asthenia, strain) scale in different voice samples

\begin{tabular}{|c|c|c|c|c|c|c|}
\hline \multirow{2}{*}{ G } & \multicolumn{2}{|c|}{ Sustained vowel } & \multirow{2}{*}{$p$} & \multicolumn{2}{|c|}{ Connected speech } & \multirow{2}{*}{$p$} \\
\hline & Samples $(\mathrm{n}=101)$ & Mean (SD) & & Samples $(\mathrm{n}=101)$ & Mean (SD) & \\
\hline 0 & 27 & $6.02(4.54)$ & $<0.001$ & 26 & $2.63(3.93)$ & $<0.001$ \\
\hline 1 & 37 & $15.67(8.44)$ & & 41 & $10.99(8.39)$ & \\
\hline 2 & 25 & $33.02(14.4)$ & & 22 & $31.65(12.34)$ & \\
\hline 3 & 12 & $82.50(18.8)$ & & 12 & 80.68 (12.99) & \\
\hline
\end{tabular}

GRBAS: grade, roughness, breathiness, asthenia, strain, SD: standard deviation

Table 6. Mean overall severity of Consensus Auditory-Perceptual Evaluation of Voice according to grade scores in 7-point GRBAS (grade, roughness, breathiness, asthenia, strain) scale in different voice samples

\begin{tabular}{lccccc}
\hline \multirow{2}{*}{$\mathrm{G}$} & \multicolumn{2}{c}{ Sustained vowel } & \multirow{2}{*}{$p$} & \multicolumn{2}{c}{ Connected speech } \\
\cline { 2 - 3 } \cline { 5 - 6 } & Samples $(\mathrm{n}=101)$ & Mean (SD) & & Samples (n=101) & Mean (SD) \\
\hline 0 & 13 & $2.69(3.54)$ & $<0.001$ & 29 & $1.91(2.89)$ \\
0.5 & 26 & $9.40(4.55)$ & & 18 & $7.61(3.23)$ \\
1 & 17 & $13.62(5.41)$ & & 16 & $12.81(5.36)$ \\
1.5 & 17 & $24.68(5.52)$ & & 12 & $23.42(7.47)$ \\
2 & 13 & $35.69(2.77)$ & & 12 & $36.92(4.62)$ \\
2.5 & 8 & $61.63(13.02)$ & & 10 & $66.05(15.33)$ \\
3 & 7 & $95.79(4.19)$ & & 4 & $93.25(3.97)$ \\
\hline
\end{tabular}

GRBAS: grade, roughness, breathiness, asthenia, strain, SD: standard deviation
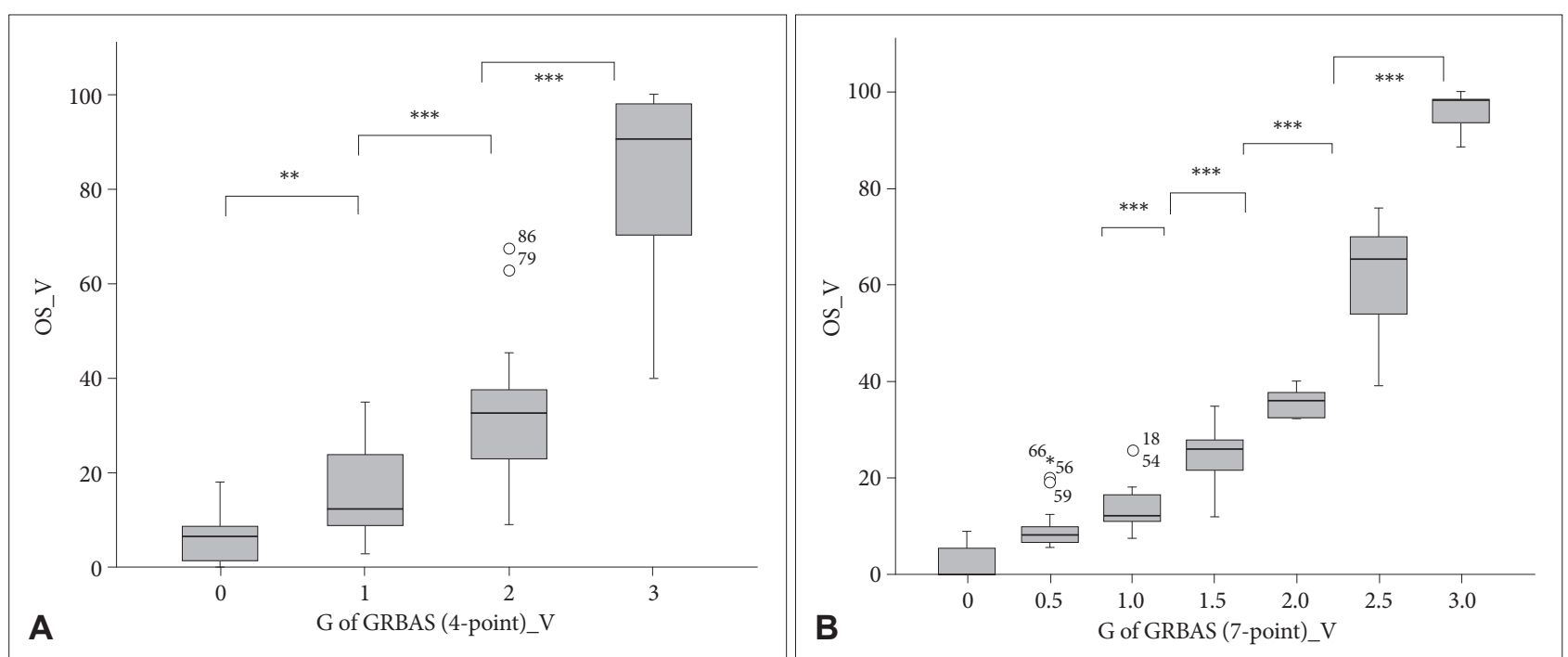

Figure 1. Comparison of OS in Consensus Auditory-Perceptual Evaluation of Voice according to G of 4-point (A) and 7-point GRBAS scale (B) in /a/ vowel. ${ }^{* *} p<0.01,{ }^{* *} p<0.001$. GRBAS: grade, roughness, breathiness, asthenia, strain, OS: overall severity, V: vowel.

모음의 경우, 4점 GRBAS척도에서는 G0 (정상)은 27명, G1 (경도)은 37명, G2 (중도)는 25명, G3 (심도)은 12명이었다. 한 편, 7점 GRBAS척도에서는 G0 (정상)은 13명, G0.5 (매우 경 도)는 26명, G1 (경도)은 17명, G1.5 (경중도)는 17명, G2 (중도) 는 13명, G2.5 (중심도)는 8명, G3 (심도)은 7명이었다.

연결 발화의 경우, 4점 $\mathrm{GRBAS}$ 척도에서는 $\mathrm{G} 0$ (정상)은 26 명, G1 (경도)은 40명, G2 (중도)는 24명, G3 (심도)은 11명이었 다. 한편, 7점 GRBAS 척도에서는 G0 (정상)은 29 명, G0.5 (매
우 경도)는 18 명, G1 (경도)은 16 명, G1.5 (경중도)는 12 명, G2 (중도)는 12 명, G2.5 (중심도)는 10명, G3 (심도)는 4명이었다.

\section{4점 GRBAS척도와 7점 GRBAS척도에 따른 CAPE-V 점수}

모음의 4점 $\mathrm{GRBAS}$ 척도 및 7점 $\mathrm{GRBAS}$ 척도의 $\mathrm{G}$ 점수와 $\mathrm{CAPE}-\mathrm{V}$ 의 OS (전반적 중증도)의 점수 평균은 Table 5,6 과 같다.

모음 연장 발성에서 4점 $\mathrm{GRBAS}$ 척도의 $\mathrm{CAPE}-\mathrm{V}$ 의 'OS' 점 수는 점수는 $\mathrm{G} 0(\mathrm{n}=27)$ 은 $6.02 \pm 4.54 \mathrm{~mm}, \mathrm{Gl}(\mathrm{n}=37)$ 은 
$15.67 \pm 8.44 \mathrm{~mm}, \mathrm{G} 2(\mathrm{n}=25)$ 는 $33.02 \pm 14.4 \mathrm{~mm}, \mathrm{G} 3(\mathrm{n}=$ 12)은 $82.50 \pm 18.8 \mathrm{~mm}$ 였으며, 일원분산분석 결과, $\mathrm{CAPE}-\mathrm{V}$ 의 $\mathrm{OS}$ 값은 $\mathrm{G}$ 점수에 따라 유의한 차이를 보였으며 $[\mathrm{F}(3,97]=$ 93.34, $p<0.001]$, Bonferroni 사후 검정 결과 $\mathrm{G} 0-\mathrm{G} 1$ ( $p=$ 0.004), G1-G2 ( $p<0.001), \mathrm{G} 2-\mathrm{G} 3$ ( $p<0.001)$ 간에 모두 유 의한 차이를 보였다(Table 5, Figure 1).

7점 $\mathrm{GRBAS}$ 척도의 $\mathrm{G}$ 척도 점수에 따른 $\mathrm{CAPE}-\mathrm{V}$ OS 점수 는 7점 $\mathrm{GRBAS}$ 척도의 경우, $\mathrm{G0}$ ( $\mathrm{n}=13)$ 은 $2.69 \pm 3.54 \mathrm{~mm}$, $\mathrm{G} 0.5$ ( $\mathrm{n}=26)$ 는 $9.40 \pm 4.55 \mathrm{~mm}, \mathrm{G1}(\mathrm{n}=17)$ 은 $13.62 \pm 5.41$ $\mathrm{mm}, \mathrm{G} 1.5(\mathrm{n}=17)$ 는 $24.68 \pm 5.52 \mathrm{~mm}, \mathrm{G} 2(\mathrm{n}=13)$ 는 $35.69 \pm$ $2.77 \mathrm{~mm}, \mathrm{G} 2.5(\mathrm{n}=8)$ 는 $61.63 \pm 13.02 \mathrm{~mm}, \mathrm{G} 3(\mathrm{n}=$ 7)은 $95.79 \pm 4.19 \mathrm{~mm}$ 였다. $\mathrm{G}$ 점수의 중증도 집단 간 $\mathrm{CAPE}-\mathrm{V}$ 의 $\mathrm{OS}$ 평균 점수의 차이를 살펴보기 위하여 일원분산분석을 실 시한 결과, 집단 간 유의한 차이를 보였으며 $[\mathrm{F}(6,94)=324.52$, $p<0.001]$, Bonferroni 사후 검정 결과 $\mathrm{G} 1-\mathrm{G} 1.5$ ( $p<0.001$ ), $\mathrm{G} 1.5-\mathrm{G} 2(p<0.001), \mathrm{G} 2-\mathrm{G} 3$ ( $p<0.001)$ 간에 유의한 차이 를 보였으나, G0-G0.5 ( $p=0.015$ )와 G0.5-G1 ( $p=0.397$ )은 유의한 차이를 보이지 않았다(Table 6, Figure 1).

한편, 연결 발화에 대한 4점 GRBAS 척도의 $\mathrm{G}$ 점수와 7점 GRBAS척도의 $\mathrm{G}$ 점수에 따른 $\mathrm{CAPE}-\mathrm{V}$ OS의 점수 평균은 Table 5, 6에 나타내었다. 4점 GRBAS척도의 경우, $\mathrm{G0}(\mathrm{n}=26)$ 의 $2.63 \pm 3.94 \mathrm{~mm}, \mathrm{G} 1(\mathrm{n}=40)$ 은 $10.99 \pm 8.39 \mathrm{~mm}, \mathrm{G} 2$ ( $\mathrm{n}=$
24)는 $31.65 \pm 12.34 \mathrm{~mm}, \mathrm{G} 3(\mathrm{n}=11)$ 은 $80.68 \pm 12.99 \mathrm{~mm}$ 였 으며, 일원분산분석 결과, $\mathrm{CAPE}-\mathrm{V}$ 의 OS값은 $\mathrm{G}$ 점수에 따라 유의한 차이를 보였으며 $[\mathrm{F}(3,97)=212.45, p<0.001]$, Bonferroni 사후 검정 결과 $\mathrm{G} 0-\mathrm{G} 1$ ( $p=0.003), \mathrm{G} 1-\mathrm{G} 2(p<0.001)$, $\mathrm{G} 2-\mathrm{G} 3(p<0.001)$ 간에 모두 유의한 차이를 보였다(Figure 2). 7점 GRBAS척도의 경우, $\mathrm{G} 0$ ( $\mathrm{n}=29$ )은 $1.91 \pm 2.89 \mathrm{~mm}, \mathrm{G} 0.5$ ( $\mathrm{n}=18)$ 는 $7.61 \pm 3.23 \mathrm{~mm}, \mathrm{G1}(\mathrm{n}=16)$ 은 $12.81 \pm 5.36 \mathrm{~mm}$, $\mathrm{G} 1.5(\mathrm{n}=12)$ 는 $23.42 \pm 7.47 \mathrm{~mm}, \mathrm{G} 2(\mathrm{n}=12)$ 는 $36.92 \pm$ $4.62 \mathrm{~mm}, \mathrm{G} 2.5$ ( $\mathrm{n}=10)$ 는 $66.05 \pm 15.33 \mathrm{~mm}, \mathrm{G} 3(\mathrm{n}=$ 4)은 $93.25 \pm 3.97 \mathrm{~mm}$ 였으며, 일원분산분석을 실시한 결과, 집단 간 유의한 차이를 보였다 $[\mathrm{F}(6,94)=324.52, p=0.000]$. Bonferroni 사후 검정 결과 $\mathrm{G} 0-\mathrm{G} 0.5$ ( $p=0.08$ )와 $\mathrm{G} 0.5-\mathrm{G} 1$ ( $p=$ $0.422), \mathrm{G1}-\mathrm{G} 1.5$ ( $p=0.001$ ) 집단 간에는 유의한 차이를 보이 지 않았으며, G1.5-G2 ( $p=0.000), \mathrm{G} 2-\mathrm{G} 2.5$ ( $p=0.000)$, G2$\mathrm{G} 3(p=0.000)$ 간에 모두 유의한 차이를 보였다(Figure 2).

\section{GRBAS 점수 체계에 따른 청지각적 중증도 집단(G) 간 음성 표본에 따른 캡스트럼 측정치 비교}

모음의 청지각적 중증도 집단(G)에 따른 캡스트럼 측정치

4점 GRBAS 척도의 grade에 따른 연장 모음 발성에 대한 캡 스트럼 분석치의 평균과 표준 편차는 Table 7과 같다.
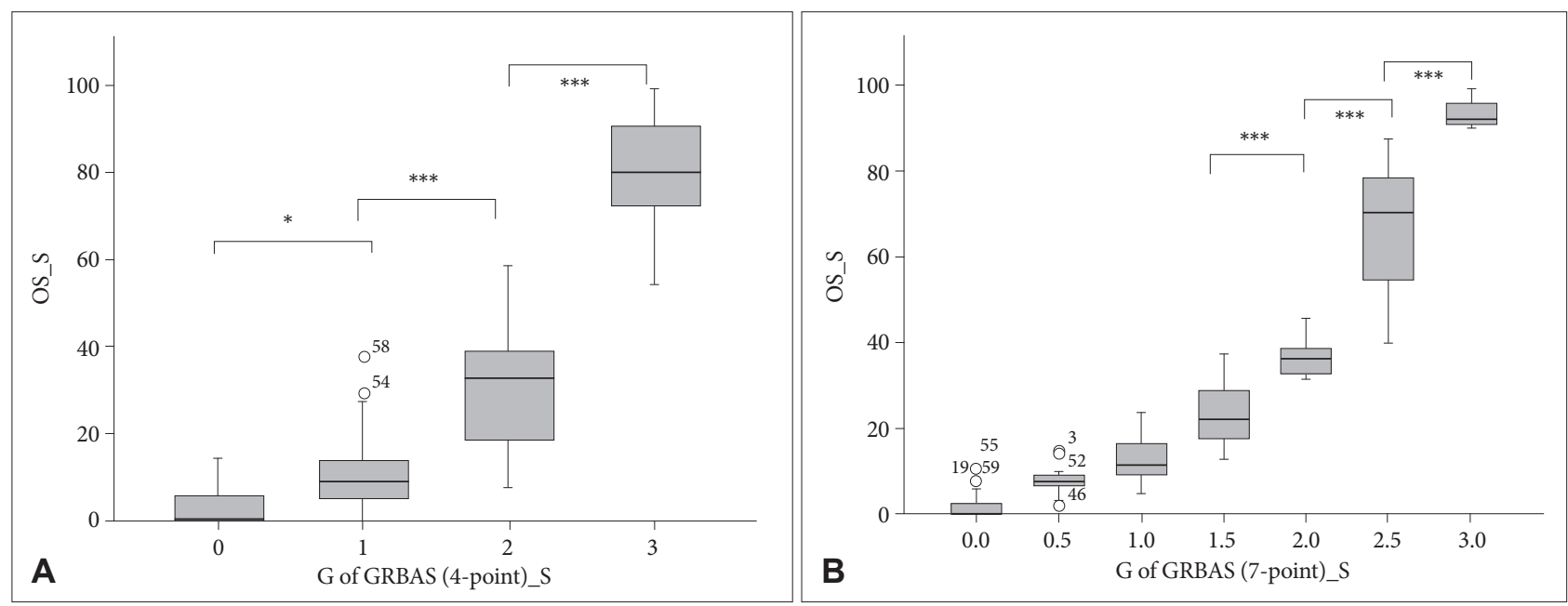

Figure 2. Comparison of OS in Consensus Auditory-Perceptual Evaluation of Voice according to G of 4-point (A) and 7-point GRBAS scale (B) in S. ${ }^{*} p<0.05,{ }^{* *} p<0.01,{ }^{* *} p<0.001$. GRBAS: grade, roughness, breathiness, asthenia, strain, OS: overall severity, S: connected speech.

Table 7. Acoustic measures based on $\mathrm{G}$ scale in 4-point GRBAS scale in /a/ sustained vowel

\begin{tabular}{lllrrrr}
\hline Acoustic measures & G0 $(\mathrm{n}=27)$ & $\mathrm{G} 1(\mathrm{n}=37)$ & $\mathrm{G} 2(\mathrm{n}=25)$ & $\mathrm{G} 3(\mathrm{n}=12)$ & Total $(\mathrm{n}=101)$ & $\mathrm{F}$ \\
\hline $\mathrm{CPP}(\mathrm{dB})$ & $12.53 \pm 1.71$ & $11.45 \pm 1.50$ & $9.74 \pm 2.44$ & $4.15 \pm 2.29$ & $10.43 \pm 3.16$ & $58.157^{* * *}$ \\
$\mathrm{~L} / \mathrm{H}$ ratio $(\mathrm{dB})$ & $33.52 \pm 6.50$ & $33.00 \pm 4.46$ & $30.03 \pm 4.12$ & $25.22 \pm 8.79$ & $31.45 \pm 6.16$ & $7.596^{* * *}$ \\
\hline
\end{tabular}

Means \pm standard deviation. ${ }^{* * *} p<0.001$. CPP: cepstral peak prominence, $\mathrm{L} / \mathrm{H}$ ratio: low/high spectral ratio, GRBAS: grade, roughness, breathiness, asthenia, strain 


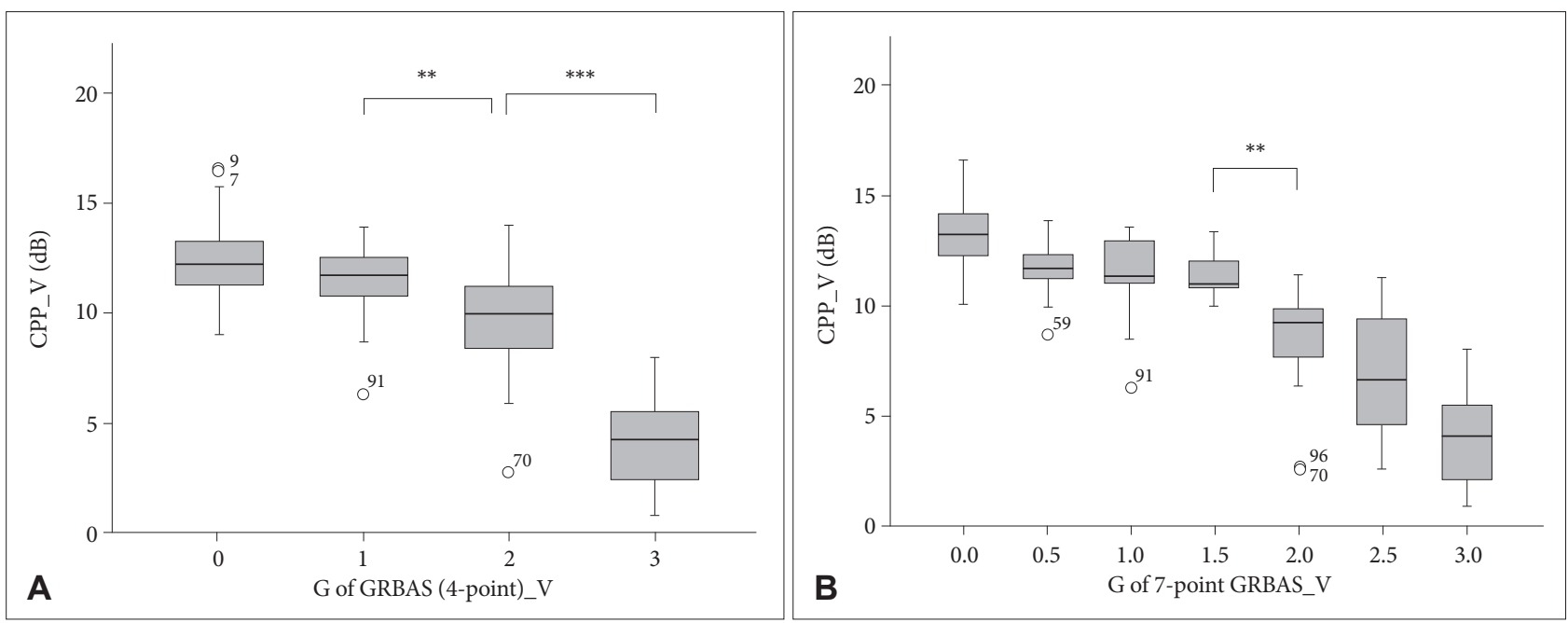

Figure 3. Comparison of CPP values according to G of 4-point (A) and 7-point GRBAS scale (B) in sustained /a/ vowel. ${ }^{* *} p<0.01,{ }^{* * *} p<$ 0.001 . CPP: cepstral peak prominence, GRBAS: grade, roughness, breathiness, asthenia, strain, $\mathrm{V}$ : vowel.
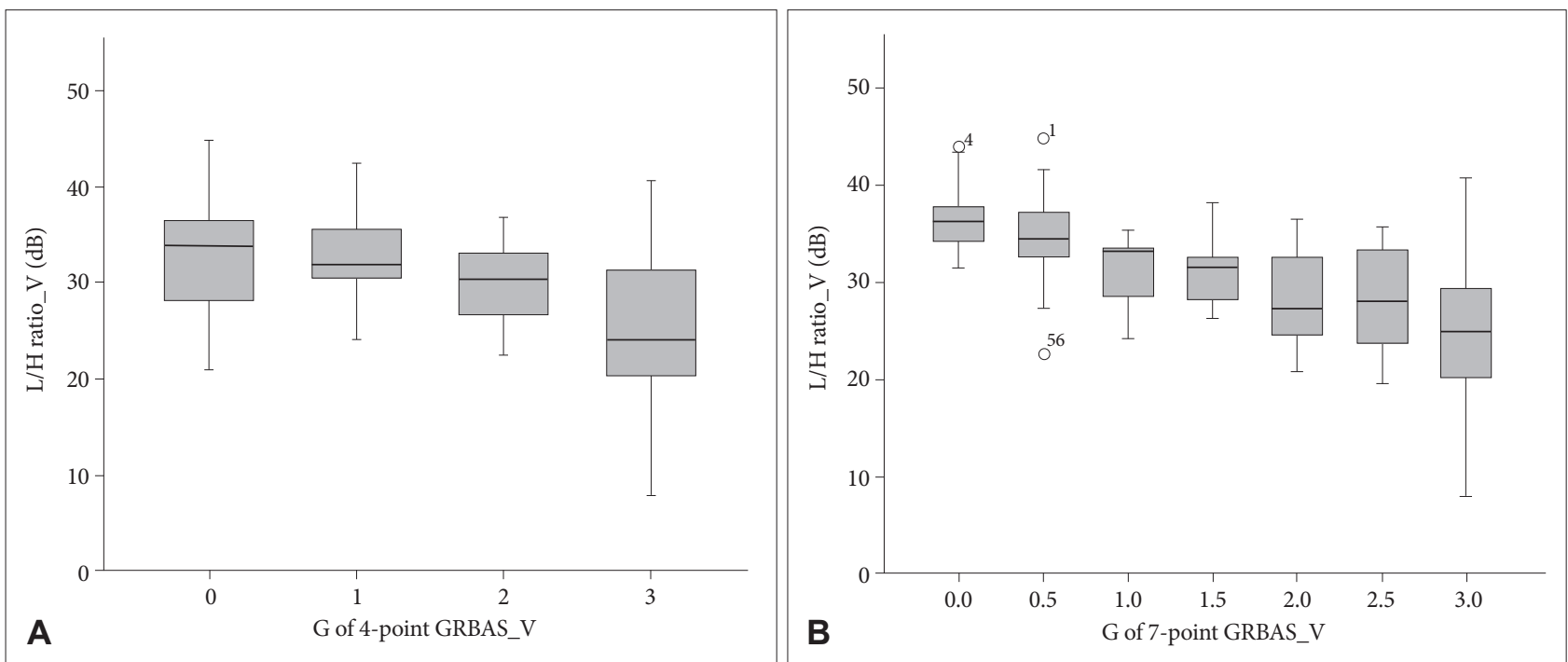

Figure 4. Comparison of $\mathrm{L} / \mathrm{H}$ ratio values according to $\mathrm{G}$ of 4-point $(\mathrm{A})$ and 7 -point GRBAS scale $(\mathrm{B})$ in sustained /a/ vowel. ${ }^{* *} p<0.01$. L/H ratio: low/high spectral ratio, GRBAS: grade, roughness, breathiness, asthenia, strain, V: vowel.

$\mathrm{CPP}$ 는 모음 연장 발성에서 $\mathrm{G} 0(\mathrm{n}=27)$ 집단은 $12.53 \pm 1.71$ $\mathrm{dB}$ 로 가장 높았고, $\mathrm{G} 1$ 집단 $(\mathrm{n}=37)$ 은 $11.45 \pm 1.50 \mathrm{~dB}, \mathrm{G} 2(\mathrm{n}=$ 25)집단은 $9.74 \pm 2.44 \mathrm{~dB}, \mathrm{G} 3(\mathrm{n}=12)$ 집단은 $4.15 \pm 2.29 \mathrm{~dB}$ 로 $\mathrm{G} 3$ 집단이 가장 낮았다(Figure 3). $\mathrm{L} / \mathrm{H}$ ratio는 G0집단(n = 27)은 $33.52 \pm 6.50 \mathrm{~dB}, \mathrm{G} 1$ 집단 $(\mathrm{n}=37)$ 은 $33.00 \pm 4.46 \mathrm{~dB}, \mathrm{G} 2$ 집단 $(\mathrm{n}=25)$ 은 $30.03 \pm 4.12 \mathrm{~dB}, \mathrm{G} 3$ 집단 $(\mathrm{n}=12)$ 은 $25.22 \pm$ $8.79 \mathrm{~dB}$ 로 $\mathrm{G}$ 점수가 높을수록 감소하였다(Figure 4).

모음의 4점 척도 GRBAS의 청지각적 중증도에 따른 집단 간 캡스트럼 측정치의 차이를 살펴보기 위하여 일원분산분석을 실시한 결과, $\mathrm{CPP}[\mathrm{F}(3,97)=58.157, p<0.001], \mathrm{L} / \mathrm{H}$ ratio $[\mathrm{F}(3,97)=7.596, p<0.001]$ 에서 모두 유의미한 차이를 나타 내었다.
한편, 7점 GRBAS척도의 $\mathrm{G}$ 에 따른 모음의 캡스트럼 측정치 는 Table 8에 제시하였다. 모음 연장 발성에서 $\mathrm{G} 0(\mathrm{n}=13)$ 집 단은 $13.29 \pm 2.02 \mathrm{~dB}$ 로 가장 높았고, $\mathrm{G} 0.5$ 집단 $(\mathrm{n}=26)$ 은 $11.66 \pm 1.20 \mathrm{~dB}, \mathrm{Gl}(\mathrm{n}=17)$ 집단은 $11.45 \pm 1.87 \mathrm{~dB}, \mathrm{Gl} .5(\mathrm{n}=$ 17)집단은 $11.38 \pm 1.07 \mathrm{~dB}, \mathrm{G} 2(\mathrm{n}=13)$ 집단은 $8.23 \pm 2.83$ $\mathrm{dB}, \mathrm{G} 2.5(\mathrm{n}=$ ) 8)집단은 $6.82 \pm 3.10 \mathrm{~dB}, \mathrm{G} 3(\mathrm{n}=$ ) 7)집단은 $3.98 \pm 2.57 \mathrm{~dB}$ 로 $\mathrm{G}$ 점수가 높을수록 $\mathrm{CPP}$ 값이 감소하였다 (Figure 3). L/H ratio는 $\mathrm{G0}(\mathrm{n}=13$ )집단은 $36.66 \pm 3.77 \mathrm{~dB}, \mathrm{G} 0.5$ 집단 $(\mathrm{n}=26)$ 은 $34.67 \pm 4.82 \mathrm{~dB}$, G1 $(\mathrm{n}=17)$ 집단은 $31.48 \pm$ $3.36 \mathrm{~dB}, \mathrm{G} 1.5(\mathrm{n}=17)$ 집단은 $31.40 \pm 3.37 \mathrm{~dB}, \mathrm{G} 2(\mathrm{n}=13)$ 집 단은 $28.55 \pm 5.45 \mathrm{~dB}, \mathrm{G} 2.5(\mathrm{n}=$ 8) 집단은 $28.17 \pm 5.98 \mathrm{~dB}$, $\mathrm{G} 3(\mathrm{n}=7)$ 집단은 $24.72 \pm 10.37 \mathrm{~dB}$ 로 $\mathrm{G}$ 점수가 높을수록 $\mathrm{L} / \mathrm{H}$ 
Table 8. Acoustic measures based on G of 7-point GRBAS scale in sustained /a/ vowel

Acoustic measures G0 $(\mathrm{n}=13)$ G0.5 $(\mathrm{n}=26)$ G1 $(\mathrm{n}=17)$ G1.5 $(\mathrm{n}=17)$ G2 $(\mathrm{n}=13) \quad$ G2.5 $(\mathrm{n}=8) \quad$ G3 $(\mathrm{n}=7) \quad$ Total $(\mathrm{n}=101) \quad$ F

$\begin{array}{llllllllll}\mathrm{CPP}(\mathrm{dB}) & 13.29 \pm 2.02 & 11.66 \pm 1.20 & 11.45 \pm 1.87 & 11.38 \pm 1.07 & 8.23 \pm 2.83 & 6.82 \pm 3.10 & 3.98 \pm 2.57 & 10.43 \pm 3.16 & 27.509^{* * *}\end{array}$

$\mathrm{L} / \mathrm{H}$ ratio $(\mathrm{dB}) \quad 36.66 \pm 3.77 \quad 34.67 \pm 4.82 \quad 31.48 \pm 3.36 \quad 31.40 \pm 3.37 \quad 28.55 \pm 5.45 \quad 28.17 \pm 5.9824 .72 \pm 10.37 \quad 31.85 \pm 5.90 \quad 7.423^{* * *}$

Means \pm standard deviation. ${ }^{* * *} p<0.001$. CPP: cepstral peak prominence, L/H ratio: low/high spectral ratio, GRBAS: grade, roughness, breathiness, asthenia, strain

Table 9. Acoustic measures based on G of 4-point GRBAS scale in connected speech

\begin{tabular}{lrrrrrr}
\hline Acoustic measures & $\mathrm{G} 0(\mathrm{n}=26)$ & $\mathrm{G} 1(\mathrm{n}=40)$ & $\mathrm{G} 2(\mathrm{n}=24)$ & $\mathrm{G} 3(\mathrm{n}=11)$ & Total $(\mathrm{n}=101)$ & $\mathrm{F}$ \\
\hline $\mathrm{CPP}(\mathrm{dB})$ & $7.49 \pm 1.58$ & $6.33 \pm 1.13$ & $5.13 \pm 1.43$ & $2.54 \pm 1.77$ & $5.83 \pm 1.87$ & $35.79^{* * *}$ \\
$\mathrm{~L} / \mathrm{H}$ ratio $(\mathrm{dB})$ & $32.17 \pm 4.40$ & $29.88 \pm 2.68$ & $27.40 \pm 3.86$ & $26.16 \pm 6.17$ & $29.48 \pm 4.37$ & $9.137^{* * *}$ \\
\hline
\end{tabular}

Means \pm standard deviation. ${ }^{* *} p<0.001$. CPP: cepstral peak prominence, $\mathrm{L} / \mathrm{H}$ ratio: low/high spectral ratio, GRBAS: grade, roughness, breathiness, asthenia, strain
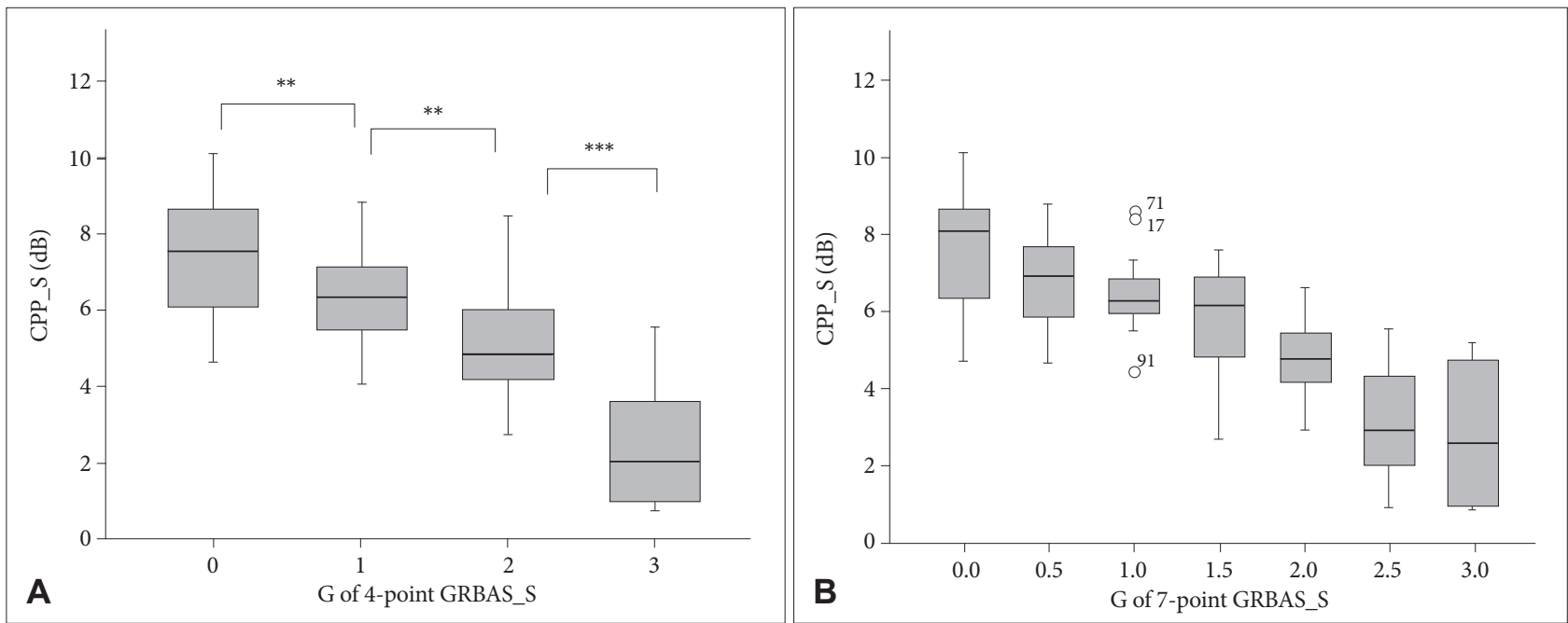

Figure 5. Comparison of CPP values according to G of 4-point (A) and 7-point GRBAS scale (B) in S. ${ }^{* *} p<0.01,{ }^{* * *} p<0.001$. CPP: cepstral peak prominence, GRBAS: grade, roughness, breathiness, asthenia, strain, S: connected speech.

ratio값도 낮았다(Figure 4). 모음의 7점 척도 GRBAS의 청지각 적 중증도에 따른 집단 간 캡스트럼 측정치의 차이를 살펴 보 기 위하여 일원분산분석을 실시한 결과, $\mathrm{CPP}[\mathrm{F}(3,97)=$ $58.157, p<0.001], \mathrm{L} / \mathrm{H}$ ratio $[\mathrm{F}(3,97)=7.790, p<0.001]$ 에서 모두 유의미한 차이를 나타내었다.

연결 발화의 청지각적 중증도 집단(G)에 따른 캡스트럼 측정치

4점 GRBAS척도의 grade에 따른 $\mathrm{CPP}$ 는 연결 발화에서도 $\mathrm{G} 0(\mathrm{n}=26)$ 집단은 $7.49 \pm 1.58 \mathrm{~dB}$ 로 가장 높았으며, $\mathrm{G} 1$ 집단 $(\mathrm{n}=$ 40)은 $6.33 \pm 1.13 \mathrm{~dB}, \mathrm{G} 2$ 집단(n = 24)은 $5.13 \pm 1.43 \mathrm{~dB}, \mathrm{G} 3$ 집단 $(\mathrm{n}=11)$ 은 $2.54 \pm 1.77 \mathrm{~dB}$ 로 가장 낮았다. 한편, $\mathrm{L} / \mathrm{H}$ ratio는 연결 발화에서도 $\mathrm{G} 0$ 집단 $(\mathrm{n}=26)$ 은 $32.17 \pm 4.40 \mathrm{~dB}$, G1집단 $(\mathrm{n}=40)$ 은 $29.88 \pm 2.68 \mathrm{~dB}, \mathrm{G} 2$ 집단 $(\mathrm{n}=24)$ 은 $27.40 \pm$ $3.86 \mathrm{~dB}, \mathrm{G} 3$ 집단 $(\mathrm{n}=11)$ 은 $26.16 \pm 6.17 \mathrm{~dB}$ 로 $\mathrm{G} 0$ 집단이 가장 높고 G3집단이 가장 낮았다(Table 9, Figure 5).

연결 발화의 4점 GRBAS척도의 청지각적 중증도에 따른 집단
간 캡스트럼 측정치의 차이를 살펴보기 위하여 일원분산분석을 실시한 결과, $\mathrm{CPP}[\mathrm{F}(3,97)=35.797, p<0.001], \mathrm{L} / \mathrm{H}$ ratio $(\mathrm{F}(3$, $97)=9.137, p<0.001$ )에서 모두 유의미한 차이를 나타내었다.

또한, 7점 GRBAS척도의 grade에 따른 연결 발화의 캡스트 럼 측정치는 Table 10에 제시하였다. 연결 발화에서 $\mathrm{CPP}$ 값은 $\mathrm{G} 0(\mathrm{n}=29)$ 집단은 $7.49 \pm 1.65 \mathrm{~dB}$ 로 가장 높았고, $\mathrm{G} 0.5$ 집단 $(\mathrm{n}=18)$ 은 $6.68 \pm 1.23 \mathrm{~dB}, \mathrm{G} 1(\mathrm{n}=16)$ 집단은 $6.40 \pm 0.98$ $\mathrm{dB}, \mathrm{G} 1.5(\mathrm{n}=12)$ 집단은 $5.81 \pm 1.54 \mathrm{~dB}, \mathrm{G} 2(\mathrm{n}=12)$ 집단은 $4.77 \pm 1.01 \mathrm{~dB}, \mathrm{G} 2.5(\mathrm{n}=10)$ 집단은 $3.19 \pm 1.56 \mathrm{~dB}, \mathrm{G} 3(\mathrm{n}=$ 4)집단은 $2.84 \pm 2.23 \mathrm{~dB}$ 로 $\mathrm{G}$ 점수가 높을수록 $\mathrm{CPP}$ 값이 감소 하였다. $\mathrm{L} / \mathrm{H}$ ratio는 $\mathrm{G} 0(\mathrm{n}=29)$ 집단은 $31.89 \pm 4.02 \mathrm{~dB}$, $\mathrm{G} 0.5$ 집단 $(\mathrm{n}=18)$ 은 $31.37 \pm 3.31 \mathrm{~dB}, \mathrm{G} 1(\mathrm{n}=16)$ 집단은 $29.21 \pm 2.96 \mathrm{~dB}, \mathrm{G} 1.5(\mathrm{n}=12)$ 집단은 $28.44 \pm 4.19 \mathrm{~dB}, \mathrm{G} 2$ $(\mathrm{n}=12)$ 집단은 $26.65 \pm 3.82 \mathrm{~dB}, \mathrm{G} 2.5(\mathrm{n}=10)$ 집단은 $23.96 \pm$ $3.75 \mathrm{~dB}, \mathrm{G} 3(\mathrm{n}=4)$ 집단은 $21.93 \pm 4.88 \mathrm{~dB}$ 로 $\mathrm{G}$ 점수가 높을 수록 $\mathrm{L} / \mathrm{H}$ ratio값도 낮았다. 
Table 10. Acoustic measures based on G of 7-point GRBAS scale in connected speech

\begin{tabular}{lrrrrrrrrr}
\hline $\begin{array}{c}\text { Acoustic } \\
\text { measures }\end{array}$ & $\mathrm{G} 0(\mathrm{n}=29)$ & $\mathrm{G} 0.5(\mathrm{n}=18)$ & $\mathrm{G} 1(\mathrm{n}=16)$ & $\mathrm{G} 1.5(\mathrm{n}=12)$ & $\mathrm{G} 2(\mathrm{n}=12)$ & $\mathrm{G} 2.5(\mathrm{n}=10)$ & $\mathrm{G} 3(\mathrm{n}=4)$ & Total $(\mathrm{n}=101)$ & $\mathrm{F}$ \\
\hline $\mathrm{CPP}(\mathrm{dB})$ & $7.49 \pm 1.65$ & $6.68 \pm 1.23$ & $6.40 \pm 0.98$ & $5.81 \pm 1.54$ & $4.77 \pm 1.01$ & $3.19 \pm 1.56$ & $2.84 \pm 2.23$ & $6.06 \pm 2.03$ & $17.257^{* * *}$ \\
$\mathrm{~L} / \mathrm{H}$ ratio $(\mathrm{dB})$ & $31.89 \pm 4.02$ & $31.37 \pm 3.31$ & $29.21 \pm 2.96$ & $28.44 \pm 4.19$ & $26.65 \pm 3.82$ & $23.96 \pm 3.75$ & $21.93 \pm 4.88$ & $29.16 \pm 4.68$ & $10.264^{* * *}$ \\
\hline
\end{tabular}

Means \pm standard deviation. ${ }^{* * *} p<0.001$. CPP: cepstral peak prominence, L/H ratio: low/high spectral ratio, GRBAS: grade, roughness, breathiness, asthenia, strain

연결 발화의 7점 GRBAS척도의 청지각적 중증도에 따른 집단 간 캡스트럼 측정치의 차이를 살펴보기 위하여 일원분산분석을 실시한 결과, $\mathrm{CPP}[\mathrm{F}(6,94)=17.257, p<0.001], \mathrm{L} / \mathrm{H}$ ratio [(F(6, 94) $=10.264, p<0.001]$ 에서 모두 유의미한 차이를 나타내었다.

\section{캡스트럼 측정치의 GRBAS척도 점수 체계에 따른 청지각적}

\section{중증도 $(\mathrm{G})$ 집단 간 변별력}

GRBAS척도별 청지각적 중증도에 따른 각 집단의 음향학적 측정치의 차이를 살펴보고 어떠한 GRBAS 점수 척도가 $\mathrm{G}$ 집 단의 중증도를 잘 변별하는지 살펴보고자 Bonferroni 사후 분 석을 실시하였다.

4점 $\mathrm{GRBAS}$ 척도의 경우, 캡스트럼 측정치인 $\mathrm{CPP}$ 는 / / / 모음 연장 발성에서 $\mathrm{G} 1-\mathrm{G} 2(p<0.01), \mathrm{G} 2-\mathrm{G} 3(p<0.001)$ 집단 간 차이만 나타내었으나(Figure 3), 연결 발화에서는 G0-G1 ( $p<$ $0.001), \mathrm{G} 1-\mathrm{G} 2(p<0.01), \mathrm{G} 2-\mathrm{G} 3$ ( $p<0.001)$ 집단 간 차이가 있었다. $\mathrm{L} / \mathrm{H}$ ratio는 / / / 모음 연장 발성과 연결 발화에서 집단 간 모두 차이가 없었다(Figure 4).

한편, 7점 GRBAS척도에서는 $\mathrm{CPP}$ 는 / / / 모음 연장 발성에 서 $\mathrm{G} 1.5-\mathrm{G} 2(p<0.01)$ 집단 간만 차이를 보였고, 연결 발화에서 $\mathrm{CPP}$ 와 L/H ratio는 G0-G0.5, G0.5-G1, G1-G1.5, G1.5-G2, $\mathrm{G} 2-\mathrm{G} 2.5, \mathrm{G} 2.5-\mathrm{G} 3$ 집단 간 모두 차이가 없었다 $(p>0.05)$ (Figure 4,5$)$.

\section{청지각적 중증도와 캡스트럼 측정치 상관성}

청지각적 평정 측정치와 캡스트럼 측정치 간 상관관계는 $\mathrm{Ta}-$ ble 11과 같다. $\mathrm{CPP}$ 측정치는 4점 $\mathrm{GRBAS}$ 척도의 $\mathrm{G}$ 점수와 7점 $\mathrm{GRBAS}$ 척도의 $\mathrm{G}$ 점수 및 $\mathrm{CAPE}-\mathrm{V}$ 의 OS와 모두 유의한 부적 상관관계를 보였다 $(p<0.01) . \mathrm{CPP}$ 와 가장 높은 상관성을 보인 것은 모음과 연결 발화의 $\mathrm{CAPE}-\mathrm{V}$ 의 OS였으며, $\mathrm{L} / \mathrm{H}$ ratio는 모든 청지각적 평정 체계의 중증도와 $<-0.41$ 의 낮은 상관성 을 보였다.

\section{DISCUSSIONS}

본 연구는 GRBAS척도의 파라미터 중 가장 재현성이 뛰어 나다고 알려져 있는 G 점수(De Bodt et al., 1997; Karnell et
Table 11. Spearman rank correlation coefficients between perceptual ratings and cepstrum measures

\begin{tabular}{lcccc}
\hline & CPP_V & $\begin{array}{c}\text { L/H } \\
\text { ratio_V }\end{array}$ & CPP_S & $\begin{array}{c}\text { L/H } \\
\text { ratio_S }\end{array}$ \\
\hline Grade_V_4-point GRBAS & $-0.709^{* *}$ & $-0.405^{* *}$ & & \\
Grade_V_7-point GRBAS & $-0.725^{* *}$ & $-0.366^{* *}$ & & \\
OS_V & $-0.743^{* *}$ & $-0.362^{* *}$ & & \\
Grade_S_4-point GRBAS & & & $-0.650^{* *}$ & $-0.293^{*}$ \\
Grade_S_7-point GRBAS & & & $-0.653^{* *}$ & $-0.303^{* *}$ \\
OS_S & & & $-0.707^{* *}$ & $-0.306^{*}$ \\
\hline
\end{tabular}

${ }^{*} p<0.05,{ }^{* *} p<0.01$. V: sustained /a/ vowel, S: connected speech, CPP: cepstral peak prominence, $\mathrm{L} / \mathrm{H}$ ratio: low/high spectral ratio, GRBAS: grade, roughness, breathiness, asthenia, strain, OS: overall severity using Consensus Auditory-Perceptual Evaluation of Voice

al., 2007)와 CAPE-V 중 재현성이 뛰어나다고 알려진 전반적 중증도(OS)를 사용하여(Zraick et al., 2011) 청지각적 평가 척 도 간 청지각적 중증도를 비교하여 임상적 유용성을 살펴보았 다. 실제 임상에서는 4점으로 평정되는 GRBAS척도의 점수 체 계로는 평정하기 애매한 경우 $0,1,2,3$ 점 사이를 추가로 더 세 분화하여 0.5 체계를 흔히 사용하기도 한다. 본 연구에서는 장 애 음성을 대상으로 $0,0.5,1,1.5,2,2.5,3$ 의 총 7점 체계를 사 용하여 모음과 연결 발화에서 청지각적 중증도를 평가하여 전 통적인 GRBAS척도의 4점 척도 및 CAPE-V와 신뢰도를 비교 하였다. 더 나아가 동일한 음성 샘플에 대해 서열 척도인 두 가 지 GRBAS척도와 시각적 아날로그 척도인 $\mathrm{CAPE}-\mathrm{V}$ 간의 점 수 분포를 각각 비교하였으며, 본 연구에서 사용된 청지각적 평 가 중 어떠한 평가 척도가 음성장애의 중증도를 변별하는 데 임상에서 유용하게 사용될 수 있을지 살펴보았다.

\section{검사자 내 및 감사자 간 신뢰도}

본 연구에서 사용한 세 가지 서로 다른 청지각적 평정 척도의 중증도에 대한 검사자 내 신뢰도는 0.828 0.947로 높은 평가자 내 신뢰도를 나타내었으며, 검사자 간 신뢰도도 0.681 0.921로 세 개의 청지각적 평정 점수 체계에서 비교적 높은 수준의 신뢰 도를 나타내었다. 특히, 검사자 내 및 검사자 간 신뢰도는 연속 척도인 $\mathrm{CAPE}-\mathrm{V}$ 의 청지각적 중증도(OS)가 $\mathrm{GRBAS}$ 척도의 $\mathrm{G}$ 에 비해 더 높게 나타났다. 이는 CAPE-V가 $100 \mathrm{~mm}$ 연속선상 
의 시각적 아날로그 척도가 연속 척도로서 모수 통계를 사용하 므로 좀 더 강한 통계적 검정력을 지닐 뿐만 아니라 $\mathrm{CAPE}-\mathrm{V}$ 는 $100 \mathrm{~mm}$ 선상에 경도, 중도, 심도와 같은 표준적 anchor를 제시해 주기 때문에 검사자 내 및 검사자 간 평정의 오차를 줄 이는 데 도움을 주는 것으로 여겨진다. Karnell et al.(2007)의 연구에서는 34 명의 음성장애 환자의 청지각적 평가를 위해 4 명 의 평정자가 검사자 간 신뢰도를 측정하였으며, GRBAS척도는 대화 수준에서 평정하였고, CAPE-V는 CAPE-V 자극어를 모 두 듣고 평정하였다. 이때, GRBAS척도의 $\mathrm{G}$ 점수의 검사자 간 신뢰도는 $0.80 ~ 0.89$ 로 다소 낮은 편이었으며, $\mathrm{CAPE}-\mathrm{V}$ 의 $\mathrm{OS}$ 척도는 0.86 0.93으로 나타나 CAPE-V가 평가자 간 신뢰도가 더 높은 것으로 보고하였다. 또한, 검사자 내 신뢰도도 $\mathrm{CAPE}-$ $\mathrm{V}$ 는 0.89 0.92였고, GRBAS척도는 0.83 0.90으로 CAPE-V 가 좀 더 높게 나타났다. 이러한 이유는 GRBAS척도는 4점 서 열 척도로서 전체 범위의 $25 \%$ 의 차이를 나타내 준다면, $\mathrm{CAPE}-\mathrm{V}$ 는 신뢰도에 훨씬 적은 영향을 주기 때문이라고 하였다.

이와 마찬가지로, Nemr et al.(2012)의 연구에서는 5년 이상 의 음성장애 평가 경험이 있는 3명의 임상가가 GRBAS척도와 $\mathrm{CAPE}-\mathrm{V}$ 를 사용하여 60 명의 음성장애 환자를 대상으로 청지각 적 평정을 실시하였다. 그 결과, 검사자 내 신뢰도는 0.923 0.985 이었고, 검사자 간 신뢰도는 4점 $\mathrm{GRBAS}$ 척도의 $\mathrm{G}$ 는 0.881 , CAPE-V의 OS는 0.911로 GRBAS척도에 비해 CAPE-V의 검 사자 간 신뢰도가 높은 것으로 나타나 본 연구의 결과와 마찬가 지로 $\mathrm{CAPE}-\mathrm{V}$ 의 신뢰도가 더 높은 것으로 나타났다. Zraick et al.(2011)의 연구에서는 11명을 대상으로 21명의 언어재활사가 청 지각적 평정을 실시하여 평가자 내 신뢰도를 비교하였는데, $\mathrm{CAPE}-\mathrm{V}$ 의 전반적 중증도는 0.57 로 낮은 편이었고, GRBAS척도 에서는 0.65 로 나타났다. 반면 검사자 간 신뢰도는 CAPE-V의 OS는 급내상관계수가 0.76으로 다른 척도에 비해 가장 높았으 며, GRBAS척도에서 $\mathrm{G}$ 점수의 급내상관계수는 0.66 이었다. 선 행 연구들에 의하면, GRBAS척도는 임상가들에게 척도가 비 교적 간단하여 신뢰롭고 편리하게 사용되어 왔으나, GRBAS척 도는 CAPE-V에 비해 음성 변화를 감지하는 데 덜 민감한 것 으로 보고하였다. 이는 GRBAS척도가 순서 척도로서 청지각적 평정 시 정상, 경도, 중도, 심도의 4 가지 중에서만 선택을 해야 하는 반면, $\mathrm{CAPE}-\mathrm{V}$ 는 음질의 변화를 더 세심하게 평가할 수 있기 때문이다.

위의 결과와는 대조적으로 Wuyts et al.(1999)은 29명의 평정 자들이 14 명의 음성장애 환자를 대상으로 $10 \mathrm{~cm}$ 의 CAPE-V 의 시각적 아날로그 척도와 6점 순서 척도 $(0,1,2,3,4,5)$ 로 변 형하여 4점 GRBAS척도와 비교하였다. 이때 $\mathrm{CAPE}-\mathrm{V}$ 는 등간 격(equal-appearing interval, EAI)척도로 청지각적 중증도를 평정하였다. 청지각적 중증도를 평가한 결과, 4점 GRBAS척도
가 CAPE-V의 시각적 아날로그 척도에 비해 더 높은 검사자 간 신뢰도를 나타내었다. 이러한 결과는 첫째, 검사자가 29명으로 평정자 수가 많아 검사자 간 일치도가 감소했을 가능성이 있다. 둘째, $\mathrm{CAPE}-\mathrm{V}$ 는 본 연구와는 달리 평정 시 $100 \mathrm{~mm}$ 선상에 왼쪽의 끝부분은 정상, 오른쪽의 끝부분은 매우 심함만을 표시 해 주는 시각적 아날로드 척도를 사용하였다. 따라서, $0,1,2,3$ 과 같이 4개 중 하나만 선택하는 4점 척도에 비해 선택할 수 있 는 지점의 범위가 매우 넓고 다양해지므로 검사자 내 및 검사자 간 평정 시 더 많은 변이가 발생한 것으로 여겨진다. 한편, 이전 에 모든 연구들은 4점 GRBAS 서열 척도와 $\mathrm{CAPE}-\mathrm{V}$ 의 시각적 아날로그 척도의 청지각적 평정만을 비교하였으나, 본 연구에서 는 4점 GRBAS척도와 0.5점 체계로 더 세분화한 7점 GRBAS 척도와 비교하였는데, 7점 GRBAS척도의 청지각적 중증도 $(\mathrm{G})$ 에 대한 검사자 간 신뢰도는 4점 GRBAS척도보다 낮게 나타났 다. 이는 7점 GRBAS척도가 4점 GRBAS척도에 비해 좀 더 세 심하게 음질의 중증도를 분석할 수 있으나, 선택의 평정 점수가 7점으로 좀 더 복잡해졌기 때문에 개인 간 변이가 더 심하게 나타난 것으로 추측할 수 있겠다.

\section{4점 GRBAS척도, 7점 GRBAS척도, CAPE-V에 따른 청지각적 평정}

일반적으로 $\mathrm{GRBAS}$ 척도와 $\mathrm{CAPE}-\mathrm{V}$ 는 음성장애의 원인에 상관없이 모든 종류의 음성장애를 평가하며, GRBAS척도는 일정한 간격으로 음성장애의 중증도를 평정하는 반면, 본 연구 에서 사용한 $\mathrm{CAPE}-\mathrm{V}$ 는 시각적 아날로그 척도이지만 $100 \mathrm{~mm}$ 선상에 비대칭적인 분포로 경도(mild), 중도(moderate), 심도 (severe)의 중증도를 나타내준다(Kempster et al., 2009) (Appendix).

4점 GRBAS척도와 7점 GRBAS척도를 사용하여 모음과 연 결 발화에 대한 청지각적 평정 결과, 음성 샘플(모음 vs. 연결 발 화)에 따라 청지각적 중증도가 다르게 나타났다. 이는 청지각적 평정 시 모음 연장 발성만으로는 음질의 중증도를 파악하기 어 려우며, 모음과 연결 발화를 모두 사용하여 음질을 평가하는 중요함을 시사한다. 또한, 7점 GRBAS척도에서는 4점 척도에 비해 정상이나 심도와 같이 극단점을 평가하는 경향이 감소하 였다. 이는 7점 GRBAS척도가 음질을 더 세분화하여 검사한 결과로 해석할 수 있을 것이다.

모음과 연결 발화의 CAPE-V의 OS는 두 가지 GRBAS척도 의 청지각적 중증도 $(\mathrm{G})$ 에 따라 모두 유의한 차이를 보였다. 이 러한 결과는 OS가 연속 척도이며, G가 순서 척도이지만 G가 증 가함에 따라 OS 점수도 같이 증가하는 것을 의미한다. 그러나, 4점 $\mathrm{GRBAS}$ 척도는 모음과 연결 발화에서 청지각적 중증도 $(\mathrm{G})$ 집단 간에 모두 OS 점수 분포가 유의한 차이를 보인 반면, 7점 
GRBAS척도는 모음의 경우는 $\mathrm{G} 0-\mathrm{G} 1$ 집단 간에, 연결 발화는 G0-G1.5집단 간에는 차이를 보이지 않았다. 이는 Appendix에 보이는 바와 같이, $\mathrm{CAPE}-\mathrm{V}$ 의 청지각적 중증도 $(\mathrm{OS})$ 에서는 정 상과 경도(MI) 지점이 가까이 분포하며, 중도(MO)-심도(SE)지 점이 비교적 멀리 떨어져 있는 비대칭적인 중증도 분포를 나타 내고 있기 때문에 7점 GRBAS척도로 좀 더 세분화하여 청지각 적 평정을 할 경우, 정상과 경도의 청지각적 중증도 $(\mathrm{G})$ 집단 간 $\mathrm{CAPE}-\mathrm{V}$ 의 OS 점수에 차이가 나타나지 않은 것으로 여겨진다.

\section{GRBAS 점수 체계에 따른 청지각적 중증도 집단(G) 간 음성 표본에 따른 캡스트럼 측정치}

장애 음성은 대부분 비주기적이므로 심각한 음질일수록 변 동률 분석에 부적합하고(Choi et al., 2012; Choi \& Choi, 2014), CSL의 multi-dimensional voice program (MDVP)를 사용한 변동률 분석은 음질이 좋지 않을수록 분석 실패가 발생할 수 있 으며, 연결 발화를 분석하는 데 어려움이 있다(Yu et al., 2017). 또한, 모음과 연결 발화의 캡스트럼 측정치인 캡스트럼 현저성 (CPP)이 청지각적 평정과 가장 상관이 높은 것으로 알려져 있으 며(Awan et al., 2014), 장애 음성 중증도 변별에 가장 유용한 음 향 지표라고 하였다(Yu et al., 2017). Pyo et al.(1999)의 연구에 서는 성대폴립 환자 30 명을 대상으로 모음 연장 발성을 통해 $\mathrm{GRBAS}$ 척도와 $\mathrm{MDVP}$ 측정치 간 상관성을 살펴보았다. 그 결 과, $\mathrm{G}$ 척도와 $\mathrm{MDVP}$ 측정치 간에 가장 상관성이 높게 나타났으 며, 특히, G와 R척도는 음도 변이 및 강도 변이 관련 변인들과 모두 높은 상관성을 보였으나, 음도 변이보다는 강도 변이 관련 변인들과 상관성이 더 높게 나타났다. 본 연구에서는 다양한 기능적, 기질적, 및 신경학적 음성장애 환자를 포함하였는데 $\mathrm{G} 3$ 으로 평정된 음성장애의 경우, $\mathrm{MDVP}$ 를 사용한 변동률 분 석이 어려운 경우가 있었다. 또한, 본 연구에서는 모음뿐 아니라 연결 발화 분석이 가능한 캡스트럼 및 스펙트럼 측정치를 구하 여 4점 GRBAS척도와 0.5점 체계가 허용된 7점 GRBAS척도와 의 상관성을 살펴보았다. 그 결과, 4점 GRBAS척도와 7점 GRBAS척도 모두 청지각적 중증도 $(\mathrm{G})$ 가 높아질수록 모음과 연 결 발화의 $\mathrm{CPP}$ 와 L/H ratio는 감소하는 경향이 있는 것으로 나 타났다. 특히, 어떠한 GRBAS 점수 척도가 $\mathrm{G}$ 집단의 중증도를 잘 변별하는지 살펴보기 위하여 $\mathrm{G}$ 집단 간 음질과 상관성이 가 장 높다고 알려진 $\mathrm{CPP}$ 측정치를 비교하였다. 그 결과, 4점 GRBAS척도에서는 CPP가 / / / 모음 연장 발성에서 G1-G2, $\mathrm{G} 2-\mathrm{G} 3$ 집단 간 차이만 나타내었으나, 연결 발화에서는 $\mathrm{G} 0-\mathrm{G} 1$, G1-G2, G2-G3집단 간 모두 차이를 보여 비교적 청지각적 중 증도를 잘 변별해 주었다.

한편, 7점 $\mathrm{GRBAS}$ 척도에서 $\mathrm{CPP}$ 는 / / / 모음 연장 발성에서는 G1.5-G2집단 간만 차이를 보였고, 연결 발화에서 $\mathrm{CPP}$ 는 $\mathrm{G} 0-$
G0.5, G0.5-G1, G1-G1.5, G1.5-G2, G2-G2.5, G2.5-G3집단 간 모두 차이를 보이지 않았다. 따라서, 이와 같은 결과로 비추 어 볼 때 7점 GRBAS척도는 청지각적 중증도를 좀 더 세밀히 분석할 수 있으나, GRBAS 4점 척도에 비해 음성장애 중증도 를 잘 변별해 주지 못하는 것으로 여겨진다.

하지만, 청지각적 평정 측정치와 캡스트럼 측정치 간 상관관 계를 살펴본 결과, $\mathrm{CPP}$ 측정치는 4점 $\mathrm{GRBAS}$ 척도의 $\mathrm{G}$ 점수 와 7점 $\mathrm{GRBAS}$ 척도의 $\mathrm{G}$ 점수 및 $\mathrm{CAPE}-\mathrm{V}$ 의 $\mathrm{OS}$ 와 모두 유의 한 부적 상관관계를 보였다. 이러한 결과는 이전의 선행 연구와 마찬가지로 GRBAS척도는 모음과 연결 발화에서 모두 CPP와 $\mathrm{L} / \mathrm{H}$ ratio 측정치와 부적 상관관계가 있다는 결과와 유사한 결 과를 나타내었다(Choi \& Choi, 2016; Lee \& Kim, 2020; Yu et al., 2017). CPP와 가장 높은 상관성을 보인 것은 모음과 연 결 발화의 $\mathrm{CAPE}-\mathrm{V}$ 의 OS였으며, $\mathrm{L} / \mathrm{H}$ ratio는 모든 청지각적 평정 체계의 중증도와 낮은 상관성을 보였다. 본 연구에서 $\mathrm{CPP}$ 와 청지각적 평정 척도 간 상관성을 살펴본 결과, 모음의 $\mathrm{CPP}$ 와 가장 높은 상관을 보인 것은 $\mathrm{CAPE}-\mathrm{V}$ 의 OS였으며 $(\mathrm{r}=$ $-0.743)$, 7점 GRBAS 척도의 $\mathrm{G}(\mathrm{r}=-0.725)$, 4점 GRBAS척도의 $\mathrm{G}(\mathrm{r}=-0.709)$ 순이었다. 이와 마찬가지로, 연결 발화의 $\mathrm{CPP}$ 와 가장 높은 상관을 보인 것은 $\mathrm{CAPE}-\mathrm{V}$ 의 OS였으며 $(\mathrm{r}=-0.707)$, 7점 체계 GRBAS척도의 $\mathrm{G}(\mathrm{r}=-0.653)$, 4점 체계 GRBAS척 도의 $\mathrm{G}(\mathrm{r}=0.650)$ 였다. 따라서, 수정된 7점 체계 GRBAS척도 가 CAPE-V보다는 음향학적 상관이 낮았지만, 기존의 4점 체 계 GRBAS척도보다 상관성이 약간 높게 나타났다. 이는 7점 GRBAS척도가 좀 더 세분하여 청지각적 중증도 $(\mathrm{G})$ 를 분석하기 때문에 $\mathrm{CPP}$ 와 상관성이 더 높게 나타난 것으로 여겨진다. Lowell et al.(2012)의 연구에서는 캡스트럼 분석의 측정치는 GRBAS와 $\mathrm{CAPE}-\mathrm{V}$ 의 청지각적 평정과 높은 상관성을 보였고, 정상 음성과 장애 음성을 감별하는 데 가장 민감한 음향학적 지표라고 하였 으며, Choi \& Choi(2014)의 연구에서도 모음의 $\mathrm{CPP}$ 를 측정한 결과, GRBAS척도의 G, R, S와 가장 높은 상관을 보였다. Yu et al.(2017)의 연구에서도 장애 음성의 청지각적 중증도가 증가할 수록 주파수 변동률(jitter, \%), 진폭변동률(shimmer, \%), 소음 대 배음비(NHR)가 증가하는 경향을 보였으며, L/H ratio, CPP 간에 부적 상관을 보고하였다.

이상의 결과를 종합해 볼 때, 수정된 7점 GRBAS척도는 기 존의 GRBAS척도에 비해 청지각적 중증도를 보다 세밀하고 자 세히 분석할 수 있으며 객관적인 청지각적 중증도를 나타내는 음향학적 측정치와 높은 상관성을 나타내었으나, 기존의 4점 GRBAS척도에 비해 청지각적 중증도의 변별력은 감소하는 것 으로 나타났다. 따라서, 이러한 점을 고려하여 수정된 7점 GRBAS척도는 기존의 GRBAS척도 및 CAPE-V와 더불어 임 상에서 청지각적 평가 도구로서 유용하게 사용될 수 있을 것이 
다. 본 연구는 GRBAS척도를 좀 더 세분화하여 임상에서 사용 하고 있는 0.5점 체계인 7점 GRBAS척도를 표준화된 4점 $\mathrm{GRBAS}$ 척도와 $\mathrm{CAPE}-\mathrm{V}$ 와 비교하여 임상적 유용성을 살펴본 것에 의의가 있다. 본 연구의 결과를 통해 제한점과 후속 연구 에 대한 제언은 다음과 같다. 첫째, 본 연구에서는 GRBAS척도 중 가장 재현성이 높은 $\mathrm{G}$ 점수와 $\mathrm{CAPE}-\mathrm{V}$ 의 전반적 중증도만 을 비교한 제한점이 있다. 추후의 연구에서는 $\mathrm{G}$ 점수뿐 아니라 다른 척도인 $\mathrm{B}, \mathrm{R}, \mathrm{A}, \mathrm{S}$ 척도에 대한 청지각적 평가로 확대하여 7점 GRBAS척도의 임상적 유용성을 조사할 필요가 있다. 둘 째, 본 연구에서는 청지각적 평정과 가장 상관성이 높다고 알려 진 캡스트럼 측정치와 상관성을 비교하였다. 추후의 연구에서 는 7점 $\mathrm{GRBAS}$ 척도 및 $\mathrm{CAPE}-\mathrm{V}$ 와 환자 중심의 주관적 평가 도구 및 모음과 연결 발화의 공기역학적 측정치와의 상관성을 살펴볼 필요가 있다.

\section{중심 단어 : 4점 $\mathrm{GRBAS}$ 척도·7점 $\mathrm{GRBAS}$ 척도. $\mathrm{CAPE}-\mathrm{V}$. 음성장애·캡스트럼분석.}

\section{Ethical Statement \\ N/A}

\section{Acknowledgments}

This work is supported by 2020 research grant of Daegu Catholic University.

\section{Declaration of Conflicting Interests \\ There are no conflict of interests.}

\section{Funding N/A}

\section{Author Contributions}

Conceptualization: Seong Hee Choi. Data curation: Miok Yu. Formal analysis: Seong Hee Choi, Miok Yu. Writing_original draft: Seong Hee Choi. Writing - review \& editing: Chul-Hee Choi. Approval of final manuscript: all authors.

\section{ORCID iD}

Seong Hee Choi https://orcid.org/0000-0003-2365-6187

\section{REFERENCES}

Anders, L. C., Hollien, H., Hurme, P., Sonninen, A., \& Wendler, J. (1988). Perception of hoarseness by several classes of listeners. Folia Phoniatrica, 40(2), 91-100.

Awan, S. N., Roy, N., \& Cohen, S. M. (2014). Exploring the relationship between spectral and cepstral measures of voice and the Voice Handicap Index (VHI). Journal of Voice, 28(4), 430-439.

Awan, S. N., Roy, N., Jetté, M. E., Meltzner, G. S., \& Hillman, R. E. (2010). Quantifying dysphonia severity using a spectral/cepstral-based acoustic index: Comparisons with auditory-perceptual judgements from the CAPE-V. Clinical Linguistics and Phonetics, 24(9), 742-758.

Bele, I. V. (2005). Reliability in perceptual analysis of voice quality. Journal of Voice: Official Journal of the Voice Foundation, 19(4), 555-573.

Bhuta, T., Patrick, L., \& Garnett, J. D. (2004). Perceptual evaluation of voice quality and its correlation with acoustic measurements. Journal of Voice: Official Journal of the Voice Foundation, 18(3), 299-304.

Choi, S. H. (2013). Speech-Language Pathologists' voice assessment and voice therapy practices: A survey for standard clinical guideline and evidence-based practice. Communication Sciences and Disorders, 18(4), 473-485.

Choi, S. H. \& Choi, C. H. (2014). The utility of perturbation, non-linear dynamic, and cepstrum measures of dysphonia according to signal typing. Phonetics and Speech Sciences, 6(3), 63-72.

Choi, S. H. \& Choi, C. H. (2016). The effect of gender and speech task on cepstral- and spectral-measures of Korean normal speakers. Audiology and Speech Research, 12(3), 157-163.

Choi, S. H. \& Choi, H. S. (2009). Multiple average ratings of auditory perceptual analysis for dysphonia. Phonetics and Speech Sciences, 1(4), 165170 .

Choi, S. H., Zhang, Y., Jiang, J. J., Bless, D. M., \& Welham, N. V. (2012). Nonlinear dynamic-based analysis of severe dysphonia in patietns with vocal fold scar and sulcus vocalis. Journal of Voice, 26(5), 566-576.

De Bodt, M. S., Wuyts, F. L., Van de Heyning, P. H., \& Croux, C. (1997). Test-retest study of the GRBAS scale: influence of experience and professional background on perceptual rating of voice quality. Journal of Voice, 11(1), 74-80.

Eadie, T. L. \& Baylor, C. R. (2006). The effect of perceptual training on inexperienced listeners' judgments of dysphonic voice. Journal of Voice, 20(4), 527-544.

Hirano, M. (1981). Clinical Examination of Voice. Wien, NY: Springer-Verlag.

Karnell, M. P., Melton, S. D., Childes, J. M., Coleman, T. C., Dailey, S. A., \& Hoffman, H. T. (2007). Reliability of clinician-based (GRBAS and CAPE-V) and patient-based (V-RQOL and IPVI) documentation of voice disorders. Journal of Voice: Official jJournal of the Voice Foundation, 21(5), 576-590.

Kempster, G. B., Gerratt, B. R., Abbott, K. V., Barkmeier-Kraemer, J., \& Hillman, R. E. (2009). Consensus Auditory-Perceptual Evaluation Of Voice: Development of a standardized clinical protocol. American Journal of Speech-Language Pathology, 18(2), 124-132.

Kreiman, J., Gerratt, B. R., Kempster, G. B., Erman, A., \& Berke, G. S. (1993). Perceptual evaluation of voice quality: Review, tutorial, and a framework for future research. Journal of Speech and Hearing Research, 36(1), 21-40.

Lee, E. J. \& Kim, J. (2020). Comparison of acoustic and auditory-perceptual evaluation in sustained vowel and connected speech by glottal closure pattern in voice disorders. Communication Sciences and Disorders, 25(3), 738-749.

Lowell, S. Y., Kelley, R. T., Awan, S. N., Colton, R. H., \& Chan, N. H. (2012). Spectral- and cepstral-based acoustic features of dysphonic, strained voice quality. The Annals of Otology, Rhinology, and Laryngology, 121(8), 539-548.

Ma, E. P. \& Yiu, E. M. (2006). Multiparametric evaluation of dysphonic severity. Journal of Voice: Official Journal of the Voice Foundation, 20(3), 380-390.

Nemr, K., Simões-Zenari, M., Cordeiro, G. F., Tsuji, D., Ogawa, A. I., Ubrig, M. T., et al. (2012). GRBAS and CAPE-V scales: High reliability and consensus when applied at different times. Journal of Voice, 26(6), P812.E17-P812.E22.

Patel, R. R., Awan, S. N., Barkmeier-Kraemer, J., Courey, M., Deliyski, D., Eadie, T., et al. (2018). Recommended protocols for instrumental assessment of voice: American Speech-Language-Hearing Association expert panel to develop a protocol for instrumental assessment of vocal function. American Journal of Speech-Language Pathology, 27(3), 887-905.

Pyo, H. Y., Choi, S. H., Lim, S. E., Sim, H. S., Choi, H. S., \& Kim, K. M. (1999). The correlation between GRBAS scales and MDVP parameters on the pathologic voices of the patients with vocal polyps. Journal of the Korean Society of Logopedics and Phoniatrics, 10(2), 154-163.

Yu, M., Choi, S. H., Choi, C. H., \& Lee, K. (2017). Usefulness of cepstral acoustic index for estimating objective dysphonia severity. Communi- 
cation Sciences and Disorders, 22(3), 587-596.

Wuyts, F. L., De Bodt, M. S., \& Van de Heyning, P. H. (1999). Is the reliability of a visual analog scale higher than an ordinal scale? An experiment with the GRBAS scale for the perceptual evaluation of dysphonia. Journal of Voice, 13(4), 508-517.
Zraick, R. I., Kempster, G. B., Connor, N. P., Thibeault, S., Klaben, B. K., Bursac, Z., et al. (2011). Establishing validity of the consensus auditoryperceptual evaluation of voice (CAPE-V). American Journal of SpeechLanguage Pathology, 20(1), 14-22. 


\section{APPENDIX}

\section{Auditory-Perceptual Ratings}

Consensus Auditory-Perceptual Examination of Voice (CAPE-V)

Name:

Date:

Overall severity

$\mathrm{MO}$

C I

$/ 100$

$\mathrm{Ml}$

SE

4-point GRBAS: G0 G1 G2 G3

7-point GRBAS: G0 G0.5 G1 G1.5 G2 G2.5 G3 